\title{
From an international English language assessment framework to a teacher- based assessment: A study of primary English teachers' agentive perspectives and projections
}

\section{Santi Farmasari*}

Universitas Mataram

J1. Majapahit No.62, Gomong, Selaparang, Kota Mataram, Nusa Tenggara Barat 83115, Indonesia

${ }^{*}$ Corresponding Author. E-mail: santifarmasari@unram.ac.id

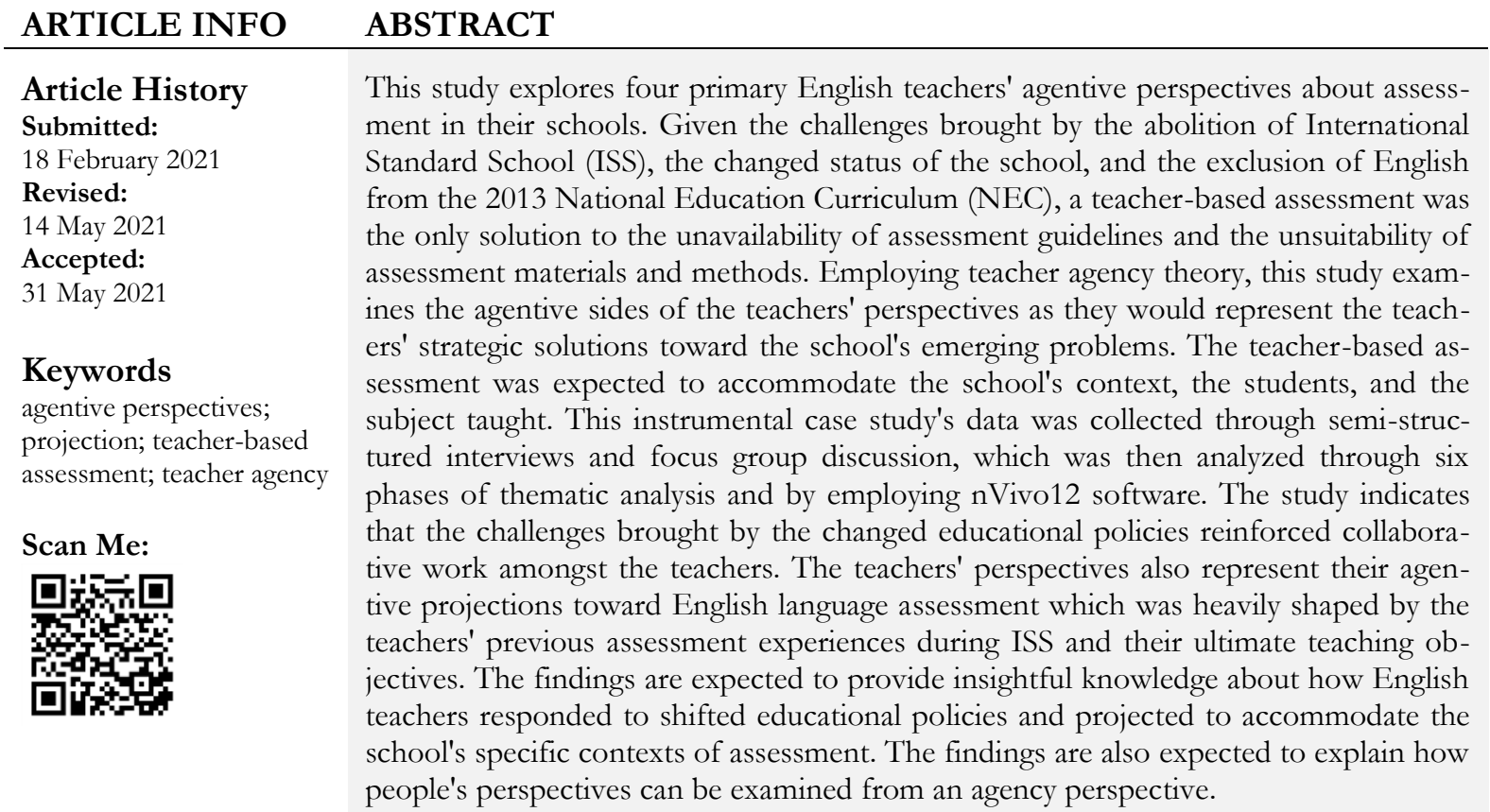

How to cite:

This is an open access article under the CC-BY-SA license. (c) (i) (2)

Farmasari, S. (2021). From an international English language assessment framework to a teacher-based assessment: A study of primary English teachers' agentive perspectives and projections. REID (Research and Evaluation in Education), 7(1), 35-45. doi:https://doi.org/10.21831/reid.v7i1.38850

\section{INTRODUCTION}

Impacts resulted from the termination of the International Standard School (ISS) system in Indonesia in early 2013 are still being felt until today, especially by former ISS. The ISS founding - through the enactment of Republic of Indonesia Act No. 20 of 2003 - was intended to inform and ultimately improve the education quality in Indonesia (Kustulasari, 2009; Sundusiyah, 2011) by integrating internationally certified education standard along with the National Education Curriculum (NEC). The abolition of ISS system created confusion at the micro-level in terms of adjustments that need to be taken to maintain the international standard teaching and assessment (Damarjati, 2013), especially for English subject as an ISS image (Farmasari, 2020). The confusions brought by the absence of further guidelines for teaching was aggravated when English is excluded from the 2013 primary school NEC, resulting in the absence of an assessment framework for English. The absence of an assessment framework has reinforced teachers to seek for solution to fill the assessment gap. In this case, Teacher-Based Assessment (TBA) is believed to 
be a strategic solution to respond to the assessment reference unavailability. TBA also aligns with English as an elective subject (Sulistiyo et al., 2020) at primary school since its design and enactment are at school and teacher level. Besides, TBA has been acknowledged to be a more appropriate scheme of assessment at school level as it enables teachers to address and integrate the specific contexts of the school and region into the assessment they develop (Dunlea et al., 2020; Janssens \& Meier, 2013). Literature shows that studies related to ISS implementation in Indonesia were mainly done during the ISS implementation, focusing on the areas of policy studies (e.g. Kustulasari, 2009; Lumbanraja, 2009; Soepriyanti, 2004); issue of national identity (e.g. Sakhiyya, 2011); teachers' professionalism (e.g. Sundusiyah, 2011); economic consequences (e.g. Coleman, 2011); and the legal aspect (e.g. Rosser \& Curnow, 2014). Studies on how school stakeholders, especially teachers, respond and adapt their academic practices to the changed policy in the aftermath of the abolition, such as the one in this study, remain scarce but much needed.

Considering ISS which used to implement internationally certified assessment for the final year students and the formative assessment was also projected as a preparation for the final international assessment, English teachers would have taken into account these previous assessment experiences into their current TBA practices (Buchanan, 2015). In another vein, the English teaching inputs that ISS students previously received were socially, culturally, pedagogically and linguistically richer than those in the NEC (Farmasari, 2020; Mahyuni et al., 2010), there need to be substantial adjustments for the assessment system. Given this problematic situation, English teachers are required to exercise their capacity to respond to the problems by taking into account the school's specific contexts and of the students (Biesta \& Tedder, 2007; Emirbayer \& Mische, 1998; Priestley et al., 2015). The problematic situations have provided opportunities for teachers to exhibit and exercise their agentive capacity in seeking strategic solutions toward emerging situations. As a starting point of examining agentive capacity, this study explores English teachers' perspectives about moving from an international assessment framework to a TBA amidst the school's given assessment contexts (X. Yan et al., 2018).

While studies about people's perspectives have been dominantly conducted to examine people's attitudes and views toward specific issues (Jerald \& Shah, 2018; Zein, 2017), this study offers an angle in which perspectives can be examined from a teacher agency point of view. This theory examines whether the participants' perspectives are agentive or less agentive by examining their responses towards the cultural, structural and material contexts of assessment in the school (Priestley et al., 2016). As visualized in Figure 1, the changed policy of ISS and English teaching in primary school is part of teacher agency's practical-evaluative element with an interplay between cultural, structural, and material aspects of assessment in the school.

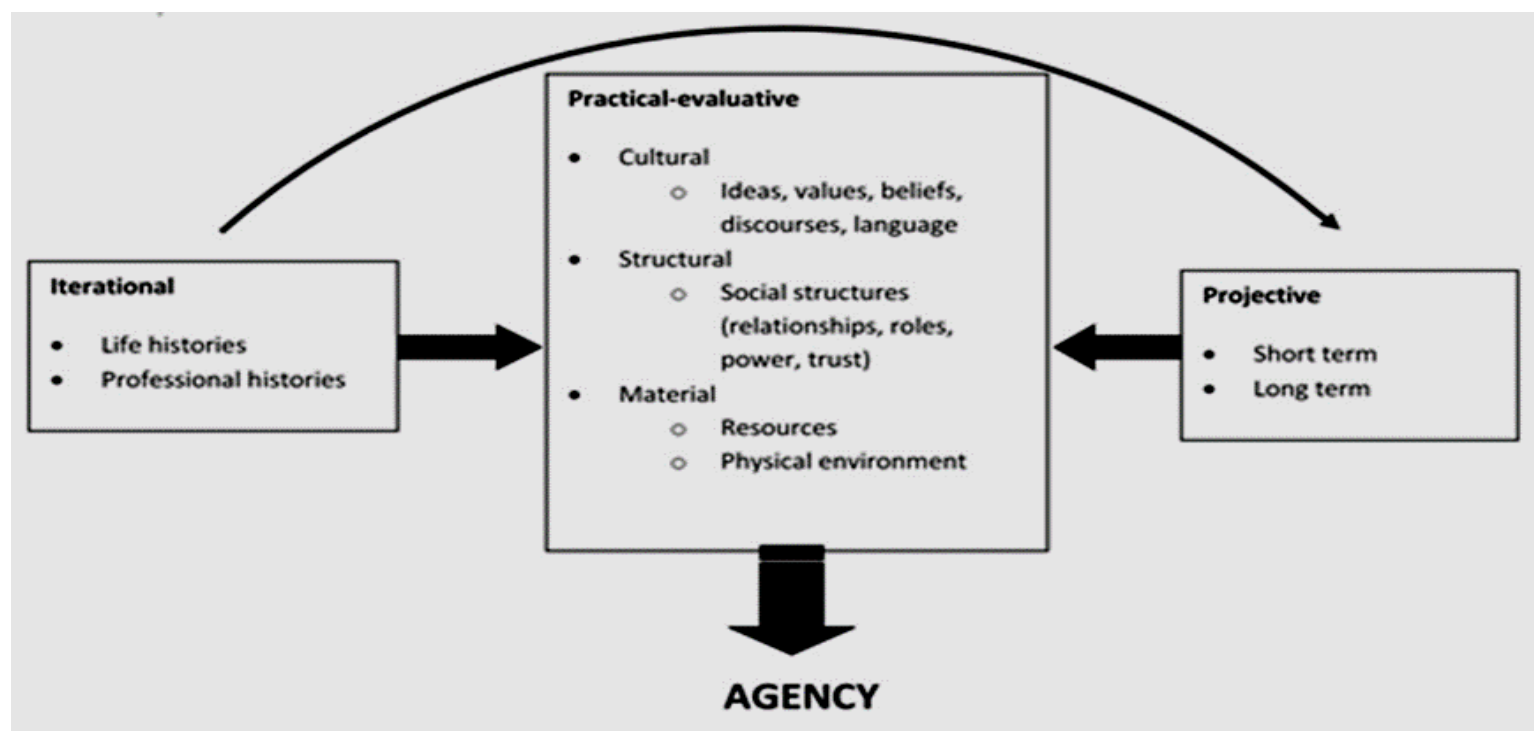

Figure 1. Teacher Agency Model (Priestley et al., 2016, p. 30) 
Given the insightful international background from the previous international assessment experiences and the practical-evaluative aspects of the assessment in the school, this study was conducted to find out (1) what agentive perspectives that the participants possess concerning the practice-evaluative aspects of assessment in the school, and (2) what projections can be identified from the participants' agentive perspectives. These findings of this study are expected to provide insightful knowledge into how English teachers in a former ISS respond to the changed educational policies and provide examples of how agentive perspectives represent projective educational practices, particularly in the assessment of English language in the context of primary schools in Indonesia.

\section{The Context of the Study}

The school where the study was undertaken used to be an International Standard School (ISS) which implemented both the national curriculum and international curriculum, i.e. the Cambridge Primary Checkpoint (CPC) in which English was included as an international subject. The English teaching and assessment complied with the CPC scheme where students had to sit on an international assessment at their final year. After the abolition of ISS in early 2013, former ISS was not given any further guidelines (Damarjati, 2013), except for a return and complete implementation of the national curriculum. The school and the teachers experienced a dilemma whether they had to comply entirely with the policy mandate or maintain the school's international curriculum; what to do with the students accustomed to the teaching pedagogy and assessment of the international standard curriculum. One of the participating teachers commented that, "If we returned to the national curriculum, the contents of the available teaching materials and assessment were too low for our students..." (Pripa).

These conditions had reinforced the teachers' personal capacity to seek a strategic solution in response to the change (Priestley et al., 2015, 2016). Therefore, it is essential to explore the English teachers' agentive perspectives about assessing the students' English achievement when moving from an international assessment framework to a teacher-based assessment.

\section{METHOD}

\section{Type of Study and the Participants}

This study is an instrumental case-study since it studied a single specific case of the English teachers' agentive perspectives. This research aims to explore an issue based on a lived experience in a "bounded system" (Creswell, 2014 p. 73). Besides, it draws on a qualitative interpretative paradigm which analyses cases in diverse schools of thoughts in the social sciences, such as social constructionism, phenomenology, and symbolic interactionism (Collins, 2010).

Table 1. The Participants' Profile

\begin{tabular}{ccccccc}
\hline Participants & Age & Gender & Role & $\begin{array}{c}\text { Leadership } \\
\text { Experience (years) }\end{array}$ & $\begin{array}{c}\text { Teaching } \\
\text { Experience (years) }\end{array}$ & Employment Status \\
\hline Pripa & 43 & Male & 6 & - & 19 & Government teacher $^{1}$ \\
Gesi & 29 & Female & 6 & - & 9 & Honorary teacher $^{2}$ \\
Miki & 30 & Male & 5 & - & 8 & Honorary teacher \\
Daru & 23 & Female & 5 & - & 8 months & Honorary teacher \\
\hline
\end{tabular}

${ }_{1}^{1}$ A government officer/teacher is a permanent position where a teacher is employed and paid by the national government

2 An honorary teacher is a non-permanent position where a teacher is employed and paid by the school.

This study was conducted in a former ISS located in a provincial city in the south-eastern part of Indonesia. The school was selected purposively as it satisfies the purpose of the study, and the participants possessed understandings of the case study or the research problems and the core phenomenon in the study (Creswell, 2014; Silverman, 2016). The participants of this study were four English teachers who were teaching Grade 5 and 6 classes (as presented in Table 1). 
Over one month (mid-August to mid-September 2018), the empirical data about the participants' agentive perspectives were collected through semi-structured interviews and focus group discussion (FGD). The teachers were then interviewed two times in order to explore their agentive perspectives and assessment projections. The second interview followed up with the teachers' responses in the first interview. The FGD was conducted one time, following the interviews, by referring to the interview data. The interview and FGD protocols and the questions were developed by following the teacher agency theory proposed by Priestley et al. (2016), representing the cultural, structural, and material contexts of English language assessment in the school.

\section{Data Analysis}

The data of this study were analyzed thematically by adopting the six phases of thematic analysis from Braun and Clarcke (2006), as presented in Table 2. The data were then analyzed inductively in Nvivo 12 Pro software. All of the codes and relevant data extracts were collated together for the later analysis stages.

Table 2. Steps to Thematic Analysis

\begin{tabular}{|c|c|c|c|}
\hline \multicolumn{2}{|r|}{ Phases } & Activities & Tools \\
\hline 1 & $\begin{array}{l}\text { Familiarisation with the data } \\
\text { collected }\end{array}$ & $\begin{array}{l}\text { - Developing understanding of the meaning of each data } \\
\text { - Discovering how each data related to the correspond- } \\
\text { ing research questions }\end{array}$ & Microsoft Word \\
\hline 2 & $\begin{array}{l}\text { Developing codes across the } \\
\text { data sets }\end{array}$ & $\begin{array}{l}\text { - Creating codes inductively } \\
\text { - Reducing and revising through a refinement process of } \\
\text { the data }\end{array}$ & NVivo12 Pro \\
\hline 3 & Searching for themes & $\begin{array}{l}\text { - A careful line-by-line reading of the excerpts } \\
\text { - Looking for repetition of words, Key-Words-In-Con- } \\
\text { text (KWIC) and shifts in content }\end{array}$ & NVivo12 Pro \\
\hline 4 & Reviewing for themes & $\begin{array}{l}\text { Developing a coding table with lists of the themes, codes } \\
\text { and their relationship to ensure the integrity and consis- } \\
\text { tency an representativeness of the data }\end{array}$ & Microsoft Word \\
\hline 5 & Defining and naming themes & $\begin{array}{l}\text { - Defining, naming and finalizing each theme } \\
\text { - Writing their descriptions and illustrating them in a ma- } \\
\text { trix }\end{array}$ & Microsoft Word \\
\hline 6 & Reporting & Reporting the findings & Microsoft Word \\
\hline
\end{tabular}

\section{FINDINGS AND DISCUSSION}

\section{Influences from the Past Assessment Practice}

Buchanan (2015) states that the contexts of teachers' previous teaching experiences heavily shaped how teachers exercised agency. As teachers engaged with the material resources from the previous practice and adjusted them to the students' current context (Stritikus, 2003), the teachers' agentive perspectives may influence their analysis, interpretation and adaptation to the available resources for their respective contexts (Smagorinsky et al., 2011).

During the ISS period with the CPC program, the English teachers received great support from the school in forms of professional development and supervisions, which helped their understanding of which assessment forms would contribute to the expected outcomes. This critical support from the school is expected to still embedded in them; thus it can affect agency (Sachs, 2016) as they were not only given opportunities to exercise their agentive role but also supported with relevant knowledge and skills (Verberg et al., 2016). However, since the abolition of the ISS policy, the school's change status, and the exclusion of English from the 2013 NEC, similar professional development programs for teachers were rarely conducted. In response to this, the participants, Miki and Gesi perceived that they needed to pursue professional development inde- 
pendently to support their assessment practices. This agentive perspective resulted from Miki's and Gesi's personal network beyond the school culture they enacted voluntarily, yet purposefully (Chisholm et al., 2019).

As a result of insightful experience from the past assessment practice, Miki perceived that her past assessment practice needed to be adopted as it aligned with the school's English learning outcomes, i.e. assessing communication skills using alternative assessment forms. In support of Miki's preferences, Pripa, admitted that he perceived the students' real-life needs to be integrated into assessment as it used to be during the ISS period with the CPC assessment. Implementing authentic assessment principles (Cheng et al., 2010), Pripa perceived that incorporating authentic use of English in the classroom context would assist students' perspectives of the use of English in their daily life. From these perspectives, the teachers' past assessment practice has given the teachers valuable insights into their current assessment practice. The assessment design and the materials provided in the CPC assessment packs (assessment samples, rubrics, and scoring system) assisted teachers to develop their current assessment tasks, assessment criteria, and scoring as Gesi stated, "... the CPC pack was complete...there was a teacher's book with suggestions for assessment tasks, scoring...I learnt from it”. With the current English teaching policy in primary school and the absence of suitable assessment materials for English, the teachers' experiences with the CPC benefit their practice in terms of guidance in developing and implementing the assessment. Even though they admitted their practice to become more challenging, the teachers understand that their role in teacher-based assessment (TBA) is critical, explained as follows.

\section{Teachers' Pivotal Role in TBA}

Due to teachers' opportunity to address the specific contexts of assessment in their respective settings, teachers' role in TBA becomes very critical (Brookhart, 2011). When explicitly asked about their perspective about their role TBA, Miki initially defined what she understands about teacher-based assessment before commenting about her role, "Teacher-Based Assessment is an assessment scheme where teachers are given authority as well as responsibilities to plan, develop and conduct an appropriate assessment."

Miki's definition of TBA implied her perspectives about her role and responsibilities in the assessment as pivotal as she needed to design and implement assessment by herself for her respective class due to the unavailability of assessment guidelines for primary school English. She further mentioned that teachers are "the right people on the right job" which is echoed by Daru that, "... the role of teachers as the key persons in the development and implementation had to be substantially recognized..." They believe that the right person to assess students is their teachers as they are in possession of knowledge about the school, the subject and the students so that the assessment could be directly monitored and improved.

Another participant, Pripa, viewed that teachers' role in TBA echoed the view that teachers should act not only as assessment developers but also as assessment enactors and evaluators (Black \& William, 2009; Davison, 2019). Further, Pripa believed that the assessment developed by teachers would be more effective than the assessment created by external parties as he stated, "TBA provides opportunities for teachers to use their knowledge about their class to develop a more direct and suitable assessment for students..."

Pripa implied that TBA provides opportunities for teachers to employ a more direct assessment of students' learning in the four language skills based on the school's goals and the students' needs. As part of teacher assessment literacy (Webb, 2002), this perspective can be viewed as the teachers' processes in collecting data directly about their students' learning. As a result, their perspectives about their pivotal role, the four teachers, Miki, Gesi, Pripa, and Daru, represent their agentive intention. The teachers resisted using external English tests in the school as the tests presumably included under-representative items to assess the students' learning achievement (Bachman, 2002; Z. Yan \& Cheng, 2015). To achieve the maximum benefit from TBA, teachers' role in ensuring whether the tasks are effectively aligning with the pre-determined learn- 
ing objectives is significant. Despite the teachers' critical role in TBA, Gesi highlighted another vital role of teachers, which can help improve assessment quality, building a positive relationship with students and parents as she stated, "Students and parents need to be involved during the preparation process... after the assessment, I always inform the results to parents so that we can work together to improve students' learning."

Teachers need to consider what role parents can play in assisting their children (Ho, 2006) such as evaluating their children's progress based on teachers' evidence (Cheng et al., 2010). Even though this involvement requires enormous time and vigorous commitment from both teachers and parents, its valuable contribution to improving students' learning is promising (Azevedo et al., 2010; Cheng et al., 2010).

In a similar vein, Miki perceived that her role in maintaining an effective communication about students' learning progress with both students and parents was es-sential and influential in achieving her goal: "...the first thing is my relationship with students and then parents". Moreover, Simpson (2017) and Lasky (2005) recognized that a positive relationship with students as a sociocultural process as a manifestation of agency as it helps students improve their assessment performance. Further, when specifically inquired about their role and responsibilities in TBA after the abolition of ISS, three teachers remarked that the situation after the ISS abolition had encouraged them to work collaboratively to maintain the quality of assessment. They believed that the opportunities to learn from and aspire to each other were facilitated during the collaborative work, while at the same time respecting each other's capacity.

\section{Learning from, Aspiring and Respecting Each Other for a Quality Assessment Practice}

As stated earlier, the situation amidst the changed national policy of ISS, the school's changed status, and the exclusion of primary English teaching in the 2013 NEC had become a driving force for collaborative work amongst the English teachers. Collaborative works were required as teachers needed to have intensive discussions and analysis of the school's assessment contexts. The work was initiated to create a more suitable English curriculum, teaching and assessment, and better English language assessment quality. The teachers admitted that the collaborative work was a place for their reciprocal learning, aspiration and respect towards each teacher's capacity. The beneficial effect of collaborative work would be achievable when teachers possess a sincere motivation to receive learning, even from younger members (Novotný \& Brücknerová, 2014). Miki stated, "I am passionate about working with other teachers, senior and junior, as they must have different knowledge and skills which will enrich my own [knowledge and skills]."

The extract above shows Miki's perspectives about working with other teachers in an intergenerational environment as a learning opportunity. Rubin and Land (2017) stated that the situational collaborative framework within a school context would create a bi-influential process where the induced and inducing teachers could influence each other's practices positively. Further, Priestley et al. (2015) also highlighted that that achievement of the agency in a school context is achieved when teachers engage with colleagues in a collaborative way maximizing their contributions in response to a problematic situation while taking into account the "cultures and structures of schooling" (p.195) they belong to.

A similar perspective was revealed from Daru, the most junior teacher who values his working team as knowledge sources. He tried to position himself as a learner. He enjoyed working with other senior teachers as they regarded him as a partner. He admitted that this acknowledgment had built his confidence when working with the team, and he was not reluctant to deliver his ideas during the teachers' meeting. Novotný and Brücknerová (2014) maintained that to facilitate every member in teamwork and learn from each other; all participants must welcome each other as a working partner, although the members are from different generations. The most senior teacher, Pripa, perceived his experience working with the three junior teachers as positive. As his juniors frequently consulted him, he could see their potential through their discussions during the meetings. He trusted that his juniors were committed to maintain and improve the qual- 
ity of English teaching and assessment, including its related programs, by stating, "I believe they [the junior teachers] are competent, they are good team. They've been working hard to maintain the quality of English teaching, they work on the right track and I will always support them..." (Pripa).

The reciprocal trust between Pripa and his junior fellows would have brought a positive atmosphere to the teachers' collaborative work in developing and implementing the TBA. As Vaughn and Faircloth (2011) stated, collaborative work amongst teachers exhibits teachers' agentive actions as they negotiate obstacles to achieve their goals. Collaborative work also facilitates teachers' capabilities to solve specific problems in their educational settings (Biesta \& Tedder, 2007). Despite the positive opportunities for reciprocal learning, the four teachers repeatedly admitted that their work is quite challenging due to some factors such as the limitation of available resources for assessment, supervision and professional development programs in the school as one of the teachers stated, "... we had to work hard to develop our own curriculum and assessment, but we don't have someone we can discuss with, a supervisor. ... it is very difficult for us now..." (Miki).

This extract represents the challenges faced by the teachers in their collaborative work. The decision taken by the Constitutional Court of the Republic of Indonesia (CCRI) to terminate the ISS implementation without a follow-up scenario for the former ISS positioned them in a difficult situation, that was aggravated when the local public university's cooperation for the supervision programs was also terminated. The teachers' collaborative work was expected to be fruitful in terms of seeking strategic solutions to the challenges they faced (Rubin \& Land, 2017). The challenges had reinforced their agentive perspectives as the teachers need to project actions "by means of their environment, rather than in their environment" (Biesta \& Tedder, 2007 p. 137).

\section{The Teachers' Projections of English Language Assessment}

As the second dimension of teacher agency model (Priestley et al., 2016), projective in this study refers to the teachers' aspirations or goals toward their TBA practice. Data indicate that the teachers' projections were influenced by the teachers' past practice and professional development and their cultural factors, i.e., their perspectives (Priestley et al., 2015). When asked about their TBA projections, the four teachers highlighted the importance of implementing Assessment for Learning (AfL) and addressing the students' characteristics as young language learners. They believed that assessment should inform them about their students' learning progress, and teachers should use the assessment result to improve their instructions as Pripa stated, "My goal is simple, assessment for learning, I will assess the students' progress towards the intended outcomes, and I will use the result to improve my teaching" (Pripa).

Similarly, Miki highlighted the importance of achieving the English teaching objectives in the school, that was enabling students to use English actively for their daily communication, "I aim my assessment to improve the students' speaking skill because it is our goal [the English teaching goal in the school]". Miki's projection may have been influenced by her role as a coordinator of English subject in the school where she endeavoured to achieve English teaching goals. Concerning assessment, Miki further stated that "the assessment will inform me about the students' problems to address them in my teaching". Miki's projections of her TBA practice show how she related assessment to teaching, reflecting an essential principle of AfL (Willis, 2011). This also reflects Miki's agentive projection in which she oriented her practice by responding to the contextual conditions (of the students) in her assessment practice (Biesta \& Tedder, 2007). Interestingly, Daru's (Miki's teaching partner) short-term TBA projection was similar to Miki's: improving the students' oral language skills. Stating that, "my assessment goals are... students can use English orally in their daily activities based on the materials taught".

This similar projection may result from Daru and Miki's daily interactions, where they discussed and shared their practices and inspired each other (York-Barr \& Duke, 2004). Miki, who was more senior in terms of teaching length and experiences with the CPC, may have in- 
fluenced Daru regarding the importance of improving students' communication skills through various methods, not only traditional paper-based tests as commonly practised in Indonesian schools (Saefurrohman \& Balina, 2016). Gesi commented about this as a common practice in the past with the CPC, "In the past [with the CPC], we used lots of methods [of assessment] ...we used portfolio, peer-assessment, performance-based, project based..." (Gesi). Gesi's comment shows her projection to incorporate various assessment methods as informed by her past assessment practice, strengthening what Buchanan (2015) theorized that teachers' past teaching experiences heavily shape their current practices.

\section{CONCLUSION}

To summarize, from the four teachers' perspectives about English language assessment in the school, some potential capitals can significantly contribute to their agentive actions during the practical-evaluative works of assessment. These capitals include the teachers' experiences with the CPC in the past, the teachers' understanding of their key role, the teachers' concerns and commitment to maintaining the symbol of quality of education in the school through collaborative work. After the abolition of ISS, the teachers' situation was instrumental and encouraging for their sense of agency (seen from their perspectives), finding strategic solutions for the challenges and finding ways to succeed within their current assessment contexts despite the struggles they faced. Furthermore, the situation also increased the teachers' awareness of the surrounding contexts afforded their projective strategies regarding constraints and opportunities. Given all the constraints, the participating teachers believe that the circumstances provided opportunities for them to find a way to determine better techniques for assessing the students' English proficiency, rather than just copying the prescribed curriculum and assessment guidelines of other subjects.

\section{REFERENCES}

Azevedo, R., Johnson, A., Chauncey, A., \& Burkett, C. (2010). Self-regulating learning with MetaTutor: Advancing the science of learning with MetaCognitive tools. In M. S. Khine \& I. M. Saleh (Eds.), New science of learning: Computers, cognition, and collaboration in education. https://asu.pure.elsevier.com/en/publications/selfregulated-\%0Alearning-with-metatutoradvancing-the-science-of-1

Bachman, L. F. (2002). Some reflections on task-based language performance assessment. Language Testing, 19(4), 453-476. https://doi.org/10.1191/0265532202lt240oa

Biesta, G., \& Tedder, M. (2007). Agency and learning in the life course: Towards an ecological perspective. Studies in the Education of Adults, 39(2), 131-149. https://doi.org/10.1080/02660830.2007.11661545

Black, P., \& William, D. (2009). Developing the theory of formative assessment. Educational Assessment, Evaluation and Accountability, 31. https://link.springer.com/article/10.1007/s11092-008-9068-5

Braun, V., \& Clarcke, V. (2006). Using thematic analysis in psychology. Qualitative Research in Psychology, 3(2), 77-101. https://doi.org/10.1191/1478088706qp063oa

Brookhart, S. M. (2011). Educational assessment knowledge and skills for teachers. Educational Measurement: Issues and Practice, 30(1), 3-12. https://doi.org/10.1111/j.17453992.2010.00195.x

Buchanan, R. (2015). Teacher identity and agency in an era of accountability. Teachers and Teaching, 21(6), 700-719. https://doi.org/10.1080/13540602.2015.1044329 
Campbell, C. M., \& O’Meara, K. (2014). Faculty agency: Departmental contexts that matter in faculty career. Res High Educ, 55, 49-74. https://doi.org/10.1007/s11162-013-9303-x

Cheng, L., Andrews, S., \& Yu, Y. (2010). Impact and consequences of school-based assessment (SBA): Students' and parents' views of SBA in Hong Kong. Language Testing, 28(2), 221249. https://doi.org/10.1177/0265532210384253

Chisholm, J., Alford, J., Halliday, L., \& Cox, F. (2019). Teacher agency in English language arts teaching: A scoping review of the literature. English Teacbing: Practice \& Critique, 18(2), 124 152. https://doi.org/10.1108/ETPC-05-2019-0080

Coleman, H. (2011). Allocating resources for English: The case of Indonesia's English medium in international standard schools. In H. Coleman (Ed.), Dreams and realities: Developing countries and the English langauge. The British Council. https://www.researchgate.net/publication/313576556_Allocating_resources_for_Engli\%0 Ash_The_case_of_Indonesia's_English_medium_International_Standard_Schools

Collins, H. (2010). Creative research: The theory and practice of research for the creative industries. AVA Academia.

Creswell, J. W. (2014). Educational research: Planning, conducting and evaluating quantitative and qualitative research. Pearson.

Damarjati, D. (2013, April 10). Mendikbud belum putuskan status sekolah kategori mandiri pasca RSBI. Detik. News. http:/ / news.detik.com/read/2013/01/13/131732/

Davison, C. (2019). Using assessment to enhance learning in English language education. In Second bandbook of English language teaching (pp. 433-454). Springer. https://doi.org/10.1007/978-3-030-02899-2_21

Dunlea, J., Fouts, T., Joyce, D., \& Nakamura, K. (2020). EIKEN and TEAP: How two test systems in Japan have responded to different local needs in the same contexts. In L. I-. Su, C. J. Weir, \& J. R. W. Wu (Eds.), English language proficiency testing in Asia: A new paradigm bridging lobal and local contexts. Routledge.

Emirbayer, M., \& Mische, A. (1998). What is agency? American Journal of Sociology, 103(4), 9621023.

https://www.jstor.org/stable/pdf/10.1086/231294.pdf?refreqid=excelsior\%3A110855271 58b64c5f26989ebfc406102.

Farmasari, S. (2020). Exploring teacher agency through English language school-based assessment: A case study in an Indonesian primary school [Queensland University of Technology]. https:/ / eprints.qut.edu.au/205615/

Ho, E. (2006). Social disparity of family involvement in Hong Kong. School Community Journal, 16(2), 7-26. https://www.fed.cuhk.edu.hk/ hkcisa/articles/Ho_2006_Soc_Disparity.pdf

Janssens, G., \& Meier, V. (2013). Establishing placement test fit and performance: Serving local needs. Colombian Applied Linguistics Journal, 15(1), 100-112. https://doi.org/10.14483/udistrital.jour.calj.2013.1.a07

Jerald, G., \& Shah, P. M. (2018). The impact of CEFR-aligned curriculum in the teaching of ESL in Julau District: English teachers' perspectives. International Journal of Innovative Research and $\begin{array}{lll}\text { Creative Technology, } & \text { 4(6), }\end{array}$ https://www.ijirct.org/viewPaper.php?paperId=IJIRCT1801023

Kustulasari, A. (2009). The international standard school project in Indonesia: A policy document analysis [Ohio State University]. http://rave.ohiolink.edu/etdc/view?acc_num=osu1242851740 
Lalani, S. S., \& Rodriguesa, S. (2012). Teachers' perception and practice of assessing the reading skills of young learners: A study from Pakistan. Journal on English Language Teaching, 2(4), 2333. https://doi.org/10.26634/jelt.2.4.2068

Lasky, S. (2005). A sociocultural approach to understanding teacher identity, agency and professional vulnerability in a context of secondary school reform. Teaching and Teacher Education2, 21(8), 899-916. https://doi.org/10.1016/j.tate.2005.06.003

Lumbanraja, S. (2009). Expanding international education in Indonesia: An analytical map of government and NGO construction of education policy. University of Pittsburg.

Mahyuni, M., Farmasari, S., \& Harmayani, H. (2010). Tingkat kelayakan tes Bahasa Inggris SD buatan guru di Kota Mataram.

Novotný, P., \& Brücknerová, K. (2014). Intergenerational learning among teachers: An interaction perspective. Studia Paedagogica, 19(4), 27-40. https://doi.org/10.5817/SP2014-43

Priestley, M., Biesta, G. J. J., \& Robinson, S. (2015). Teacher agency: What it is and why it matters. In R. Kneyber \& J. Evers (Eds.), Flip the system: Education from the bottom up (pp. 134-148). Routledge.

Priestley, M., Biesta, G. J. J., \& Robinson, S. (2016). Teacher agency: An ecological approach. Bloomsbury. http:/ / ebookcentral.proquest.com/lib/qut/detail.action?docID=2146745.

Rosser, A., \& Curnow, J. (2014). Legal mobilisation and justice: Insights from the Constitutional Court case on international standar school in Indonesia. The Asia Pacific Journal of Anthropology, 15(4). https://doi.org/10.1080/14442213.2014.916341

Rubin, J. C., \& Land, C. L. (2017). This is English class: Evolving identities and a litercy teacher's shifts in practice accross figured worlds. Teaching and Teacher Education, 68, 190-199. https://doi.org/10.1016/j.tate.2017.09.008

Sachs, J. (2016). Teacher professionalism: Why are we still talking about it. Teachers and Teaching, 22(4), 413-425. https://doi.org/10.1080/13540602.2015.1082732

Saefurrohman, S., \& Balinas, E. S. (2016). English teachers classroom assessment practices. International Journal of Evaluation and Research in Education, 5(1), 82-92. http://doi.org/10.11591/ijere.v5i1.4526

Sakhiyya, Z. (2011). Interrogating identity: the International Standard School in Indonesia. Culture \& Society, 19(3), 345-356. https://doi.org/10.1080/14681366.2011.607841

Silverman, D. (2016). Qualitative research. SAGE Publications.

Simpson, A. (2017). Teachers negotiating professional agency through literature-based assessment. Literacy, 51(2), 111-119. https://doi.org/10.1111/lit.12114

Smagorinsky, P., Wilson, A. A., \& Moore, C. (2011). Teaching grammar and writing: A beginning teacher's dilemma. English Education, 43(3), 262-292. https://www.jstor.org/stable/23017093?seq=1\#metadata_info_tab_contents

Soepriyanti, H. (2004). Bilingual education in international standard school in Indonesia: An analysis of policy [The University of Sunshine Coast]. http:/ / research.usc.edu.au/vital/access/manager/Repository/usc:13218

Stritikus, T. T. (2003). The interrelationship of beliefs, context, and learning: The case of a teacher reacting to language policy. Journal of Language, Identity \& Education, 2(1), 29-52. https://doi.org/10.1207/S15327701JLIE0201_2 
Sulistiyo, U., Haryanto, E., Widodo, H. P., \& Elyas, T. (2020). The portrait of primary school English in Indonesia: Policy recommendations. Education 3-13, 48(8), 945-959. https:// doi.org/10.1080/03004279.2019.1680721

Sundusiyah, A. (2011). Teachers in international standard schools: What is missing? What can be improved? What does it take in education counts? In A. Sakhiyya, A. Arsana, \& R. Mikha (Eds.), The contribution of Indonesian students studying overseas for education in Indonesia. Insight Media.

Terosky, A., O’Meara, K., \& Campbell, C. (2014). Enabling possibility: Women associate professors' sense of agency in career advancement. Journal of Diversity in Higher Education, 7 , 58-72. https://doi.org/10.1037/a0035775

Vaughn, M., \& Faircloth, B. S. (2011). Understanding teacher visioning and agency during literacy instruction. In P. L. Dunston, L. B. Gambrell, K. Headley, S. K. Fullerton, P. M. Stecker, V. R. Gilles, \& C. Bates (Eds.), 60th Yearbook of the literacy research association (pp. 156-164). Literacy Research Association. https://tigerprints.clemson.edu/cgi/viewcontent.cgi?article=1020\&context=ed_human_\% 0Advlpmnt_pub

Verberg, C. P. M., Tigelaar, D. E. H., Veen, K., \& Verloop, N. (2016). Teacher agency within the context of formative teacher assessment: An in-depth analysis. Educational Studies, 42(5), 534-552. https://doi.org/10.1080/03055698.2016.1231060

Webb, N. L. (2002). Assessment literacy in a standards-based urban education setting. The American Educational Research Association Annual Meeting, 1-23. http:/ / citeseerx.ist.psu.edu/viewdoc/download?doi=10.1.1.573.676\&rep=rep1\&type=pdf

Willis, J. (2011). Affiliation, autonomy and assessment for learning. Assessment in Education: Principles, Policy \& Practice, 18(4), 399-415. https://doi.org/10.1080/0969594X.2011.604305

Yan, X., Zhang, C., \& Fan, J. J. (2018). “Assessment knowledge is important, but...”: How contextual and experiential factors mediate assessment practice and training needs of language teachers. System, 74. https:// doi.org/10.1016/j.system.2018.03.003.

Yan, Z., \& Cheng, E. C. K. (2015). Primary teachers' attitudes, intentions and practices regarding formative assessment. Teaching and Teacher Education, 45, 128-137. https://doi.org/10.1016/jt.tate.2014.10.002

York-Barr, J., \& Duke, K. (2004). What do we know about teacher leadership?: Findings from two decades of scholarship. Review of Educational Research, 74(3), 255-316. https://doi.org/10.3102/00346543074003255

Zein, M. S. (2017). Professional development needs of primary EFL teachers: Perspectives of teachers and teacher educators. Professional Development in Education, 43(2), 293-313. https://doi.org/10.1080/19415257.2016.1156013 